\title{
Paleontological and biostratigraphical characteristics of the Badenian deposits on the Srebrenik-Donja Orahovica profile (Bosnia and Herzegovina)
}

Rudarsko-geološko-naftni zbornik

(The Mining-Geology-Petroleum Engineering Bulletin) UDC: 551

DOI: $10.17794 /$ rgn.2022.1.8

Original scientific paper

\author{
Zijad Ferhatbegović ${ }^{1}$; Amila Avdić ${ }^{2}$; Sumeja Durmić ${ }^{3}$ \\ ${ }^{1}$ Faculty of Mining, Geology and Civil engineering, University of Tuzla, Tuzla, Bosnia and Herzegovina \\ 2 Štrosmajerova 73, Zenica, Bosnia and Herzegovina \\ ${ }^{3}$ Gornja Zenica, Urije 54, Bosnia and Herzegovina
}

\begin{abstract}
This paper describes the biostratigraphic and paleontological research conducted on the geological section of SrebrenikDonja Orahovica (Northern Bosnia and Herzegovina). The samples for micropaleontological research were taken from the exploration works (eight wells and nine excavations). Based on the presence of microforaminifera, the stratigraphic level of Lower Badenian was defined. According to micropaleontological and biostratigraphic analyses within this stratigraphic level, one local foraminiferal zone was identified: zone with Trilobatus trilobus and Orbulina suturalis which represents the upper parts of the Lower Badenian. This zone is characterized by a rich microfossil community with a dominance of planktonic forms over benthic ones, normal salinity, warm sea, and basic character of the environment.
\end{abstract}

Keywords:

Foraminifera; biostratigraphy; Lower Badenian; Bosnia and Herzegovina

\section{Introduction}

Marine Miocene sediments in Bosnia and Herzegovina are present only in the area of northern Bosnia, which in the Miocene represented the southern rim of the Central Paratethys (see Figure 1). In many parts, these sediments are covered with younger deposits so data on lithofacial and biofacial features are lacking. For these reasons, an insufficient number of paleogeographic analyses of Miocene sediments have been performed. A significant contribution to the knowledge of facial, biostratigraphic, tectonic and other features of marine Miocene sediments in Bosnia and Herzegovina has been made by numerous researchers: Katzer, 1903; Stevanović and Eremija 1960; Soklić, 1964, 1982, 1988, 2001; Soklić and Vrabac, 1995; Čičić, 1964, 2002; Čičić and Jovanović, 1987; Kranjec, 1969; Eremia, 1970; Atanacković, 1977, 1981; Stojčić et al., 1978; Petrović, 1979/80; Pantić et al., 1988; Petrović et al., 1990; Vrabac, 1986, 1987, 1989, 1991, 1999, 2005, 2007; Vrabac and Mihajlović, 1990; Vrabac and Ferhatbegović, 1997; Vrabac et al., 2000; Vrabac et al., 2005; Vrabac and Ćorić, 2008; Vrabac et al., 2008; Vrabac et al., 2013; Cicha et al., 1998; Pantić et al., 1988; Ferhatbegović, 2001, 2003, 2004, 2006, 2010, 2018; Ferhatbegović and Vrabac, 2006; Ferhatbegović and Jahić, 2013; Ferhatbegović et al.,

Corresponding author: Zijad Ferhatbegović

zijad.ferhatbegovic@untz.ba
2013; Ćorić et al., 2007; Rupp and Hohenegger, 2008; Đulović et al., 2010.

According to the Basic Geological map of former Yugoslavia in scale 1:100 000, sheet Doboj (Laušević and Jovanović, 1983) Middle Miocene sediments have a large distribution and are represented by typical marine sediments. In the examined area, Middle Miocene sediments are characterized by significant lithological diversity, which is probably due to the fragmented paleorelief and coastal sedimentation regime (Vrabac et al., 2007). Badenian in northern Bosnia is characterized by significant paleogeographic changes (coastal disintegration and bottom relief, mostly normal salinity, favorable gas regime, water temperature identical to tropical to subtropical seas, shallow sea, etc.) (Pantić et al., 1988; Vrabac et al., 2007). The fossil faunal association is characterized by numerous microfauna and pteropods. At the lowest level are mostly numerous planktonic foraminifera where globigerinoid and orbitolinoid taxa are the most abundant. They are typical for the Lower Badenian foraminiferal zone Trilobatus trilobus and Orbitolina suturalis. Benthic forms are represented by buliminas and uvigerinas. In addition to numerous pteropods, there are also mollusks: Pycnodonta cochlear, Chenopus pespelicani, Tellina ottnangensis, Conus sp., and others.

The geological profile Srebrenik - Donja Orahovica (see Figure 2) represents an insufficiently known area, especially from a micropaleontological point of view. According to the current information, Badenian and Sar- 


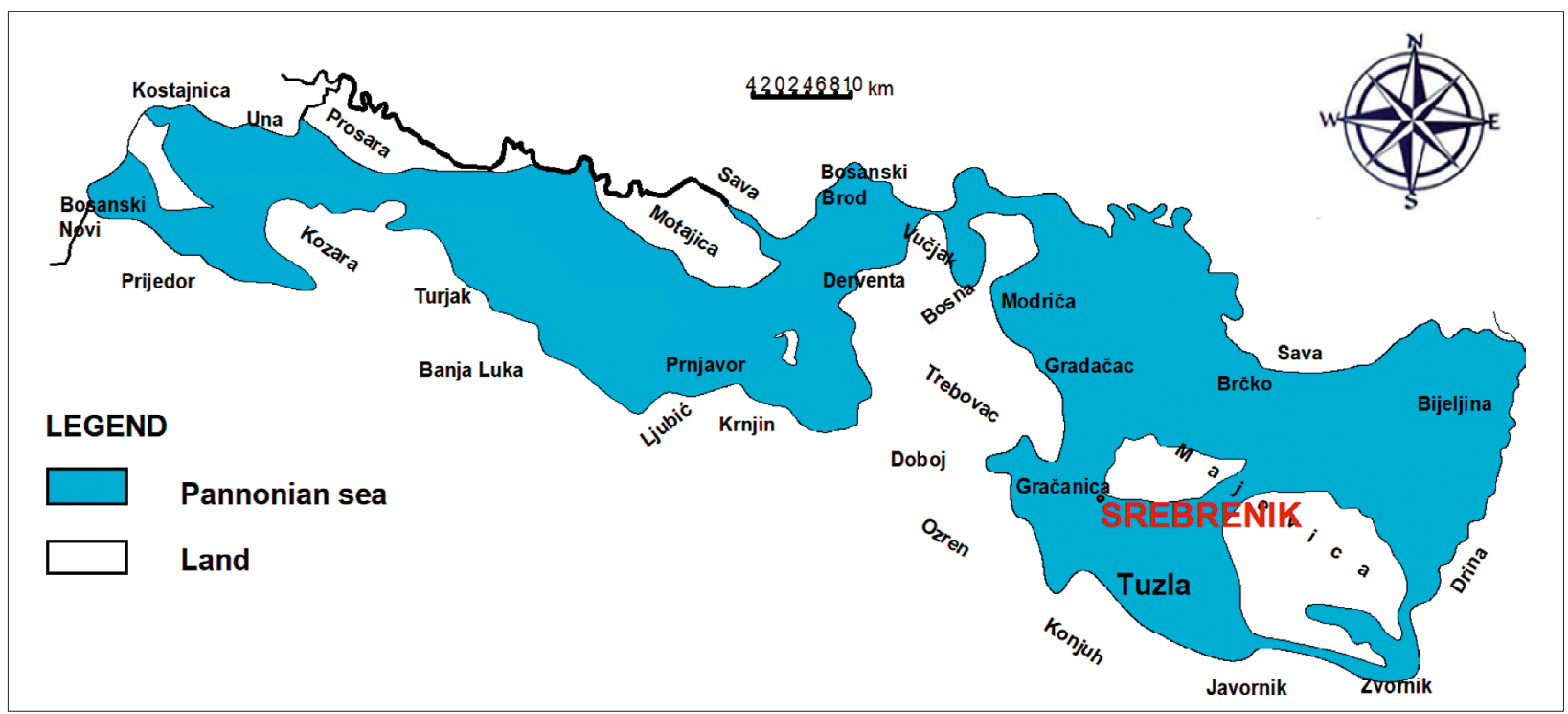

Figure 1: Paleogeographic map of northern Bosnia in the Badenian (Vrabac et al., 2007)

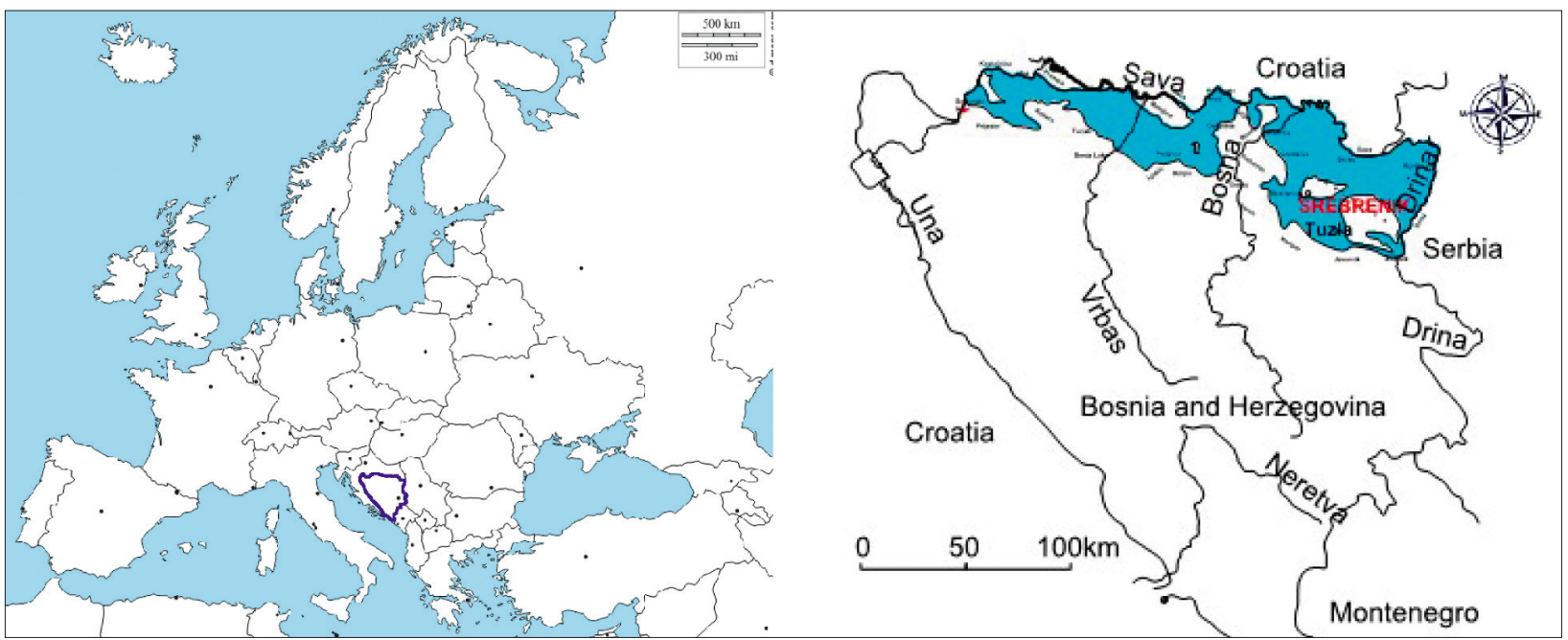

Figure 2: Geographic position of the research area (Srebrenik)
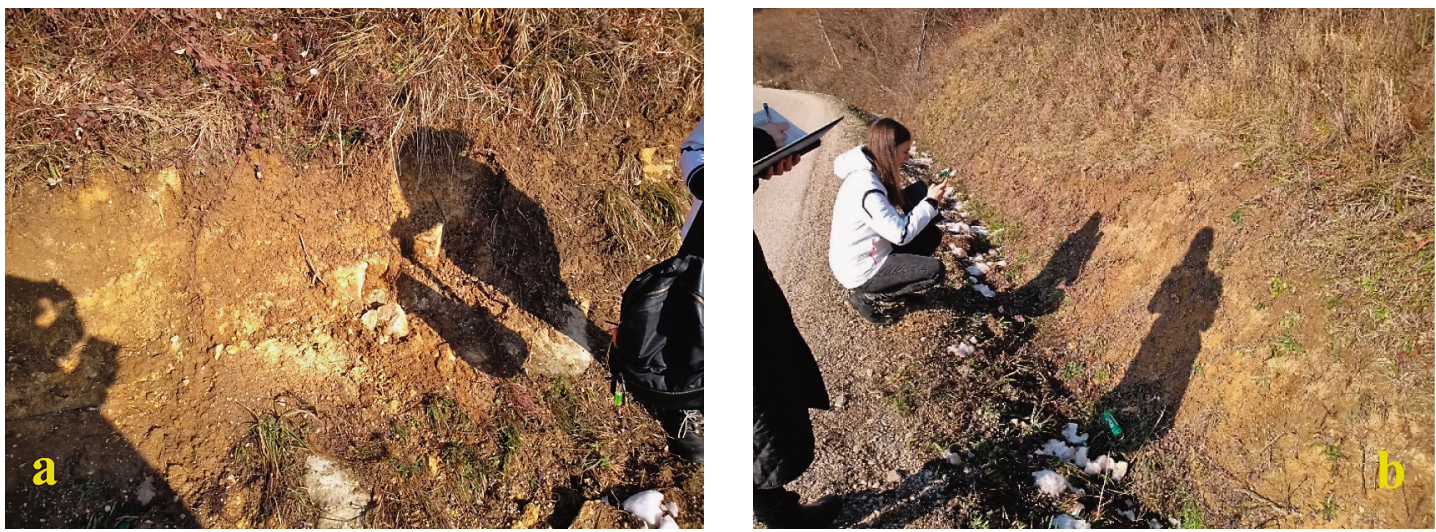

Figure 3: Very rare rock outcrops (a) and geological mapping (b) along the section Srebrenik-Donja Orahovica

matian sediments are present on the Srebrenik - Donja Orahovica exploration profile. The research aims to determine the detailed geological structure of the terrain and paleontological and biostratigraphic characteristics along with the considered profile. The lithological composition, paleontological and biostratigraphic character- 


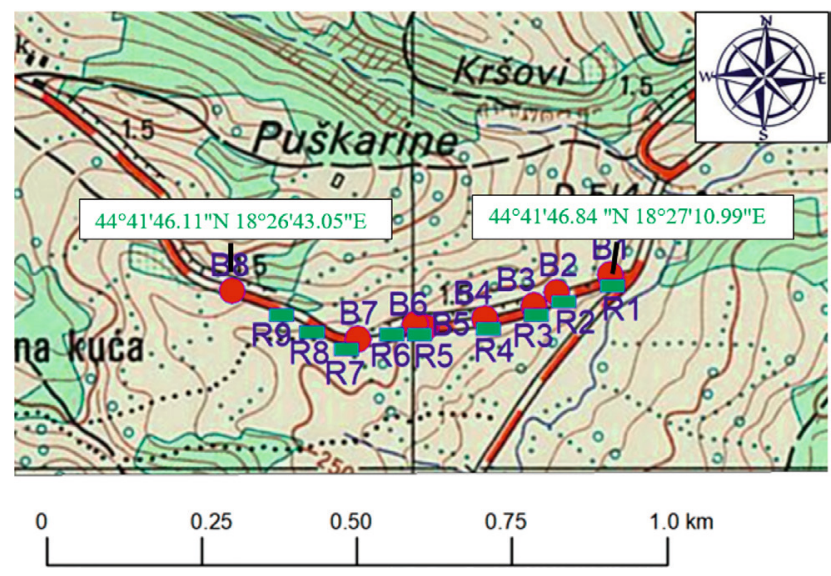

Figure 4: Position of sampling points (topographic map of Sladna sheet 1:2500o)

red spots: boreholes, green rectangles: excavations
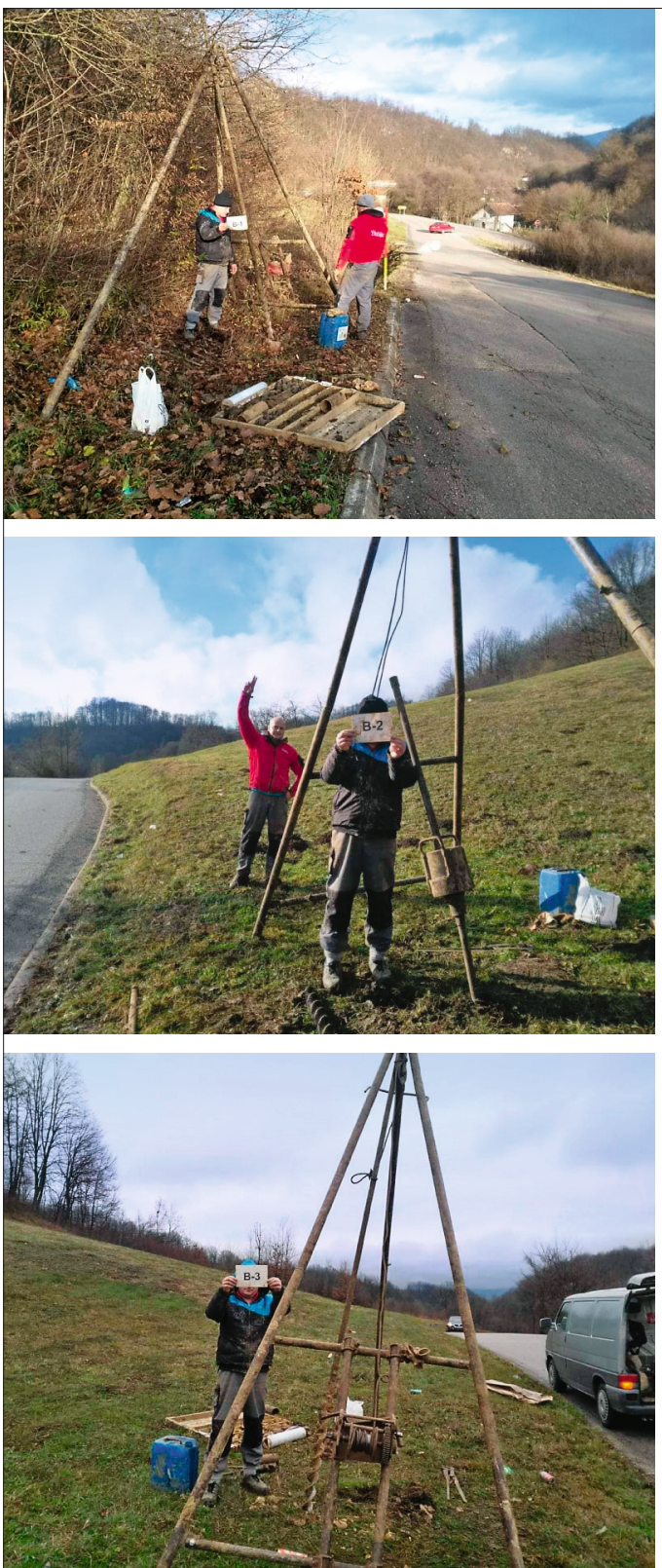

istics of this area were the main issues to be addressed, based on the data collected during the research. The research was performed using geological mapping, laboratory, and cabinet methods. Micropaleontological analyses were performed to assess the presence of foraminifera in certain stratigraphic levels and more accurately define the boundaries of different biostratigraphic units.

\section{Materials and Methods}

The research methodology is based on geological mapping (see Figure 3) and laboratory and cabinet research. The research aimed to define the biostratigraphic characteristics of sediments on the profile SrebrenikDonja Orahovica. It is $24.63 \mathrm{~km} \mathrm{NW}$ of Tuzla city and $3.25 \mathrm{~km} \mathrm{SW}$ of Srebrenik. Sampling along the road Sre-
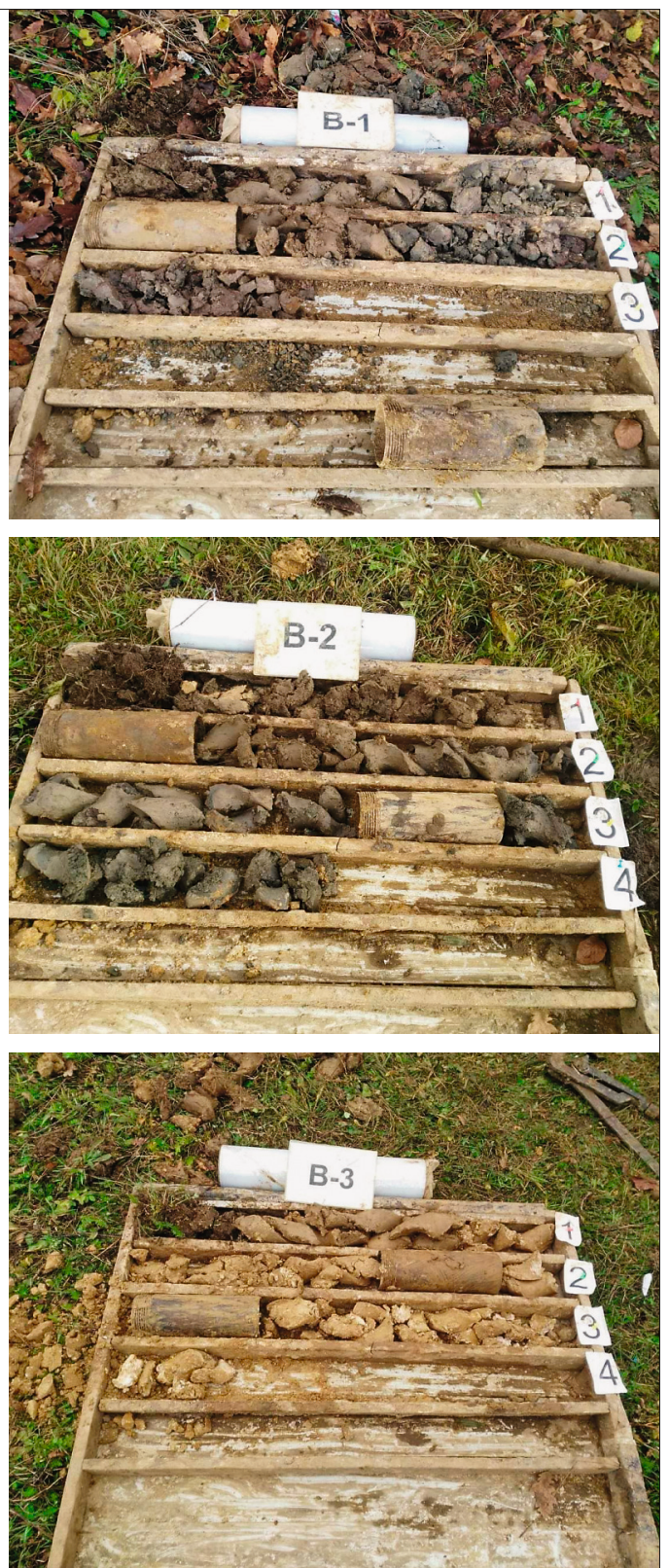

Figure 5: Exploration boreholes B-1, B-2 and B-3 

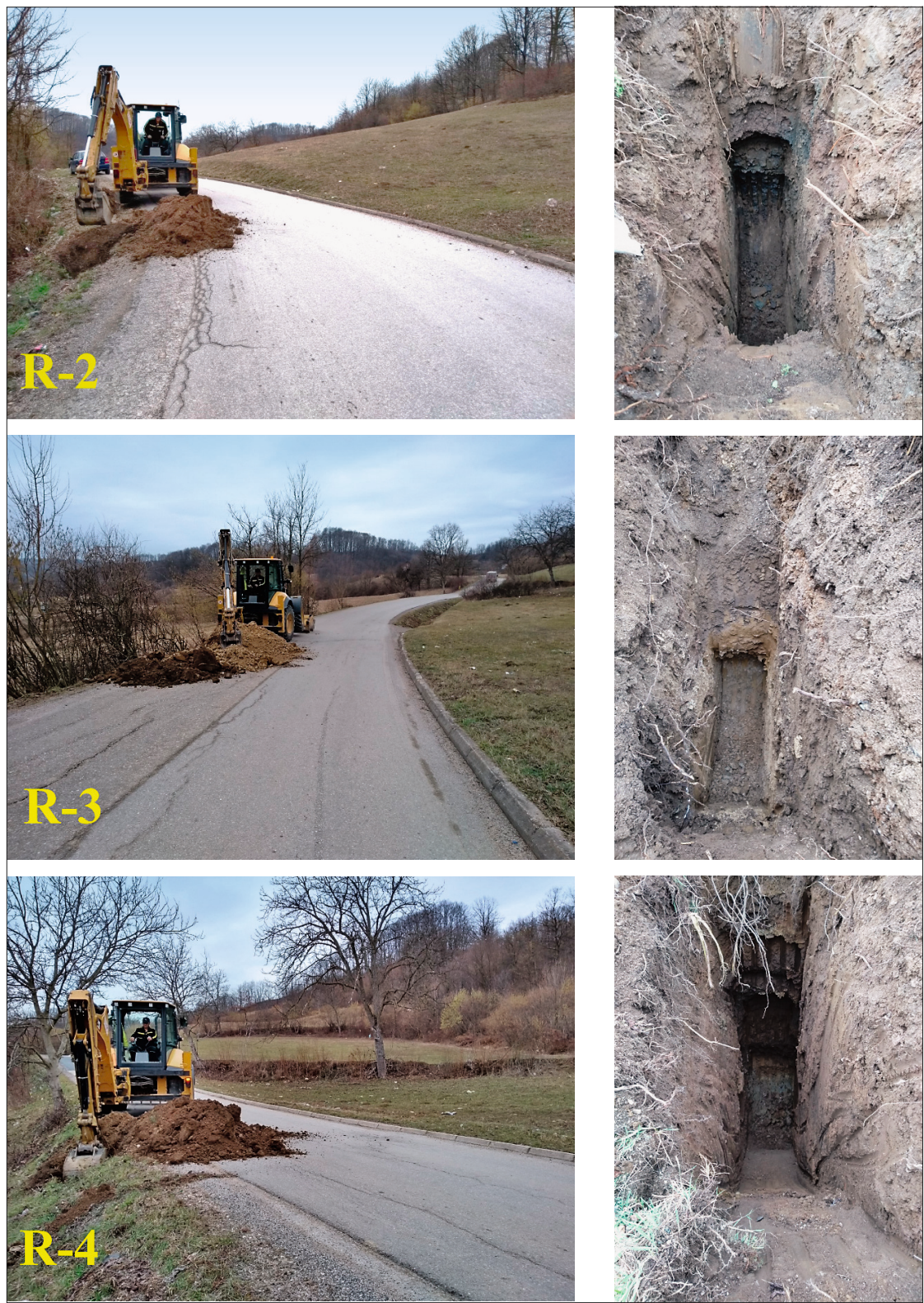

Figure 6: Exploration excavations R-2, R-3 and R-4

brenik-Donja Orahovica took place during 2019 and 2020 and was performed between $44^{\circ} 41^{\prime} 46.84$ "N $18^{\circ} 27^{\prime} 10.99^{\prime \prime} \mathrm{E}$ and $44^{\circ} 41^{\prime} 46.11^{\prime \prime} \mathrm{N} 18^{\circ} 26^{\prime} 43.05^{\prime \prime} \mathrm{E}$ over the length of 900 meters (see Figure 4).

The terrain is quite covered with soil and vegetation with very rare rock outcrops along the examined section. The study of microforaminifera was performed on 12 samples (see Figures 5-11) that were taken from investigative boreholes and excavations (B-boreholes., R-excavations). The coordinates of sampling points are shown in Table 1.

The samples after the collection were packed in special bags and marked. After that, they were wet-sieved at the Faculty of Mining, Geology, and Civil Engineering in Tuzla, using laboratory sieves with a diameter of 0.8 , $0.5,0.25$, and $0.15 \mathrm{~mm}$ (see Figure 12). The sieve fraction of $0.15 \mathrm{~mm}$ was dried and analyzed using a Leica
EZ4D stereomicroscope. For each sample with the association of microforaminifera, a photograph was taken using a digital camera built into the microscope.

\subsection{Methods for the micropaleontological examination}

Micropaleontology has become especially important in petroleum engineering. During this study, rock particles up to $1 \mathrm{~cm}$ in size were caught in a sieve. The same amount of sample was taken from each piece (the weight of the piece is 6 grams). Samples were washed with tap water, dried, labeled, and stored in bags. For micropaleontological research, the method of wet - sieving was applied, whereby the clay rocks were immersed in water with the addition of baking soda or a $15 \%$ hydrogen peroxide solution. Glauber's salt was applied to compact marls. After 

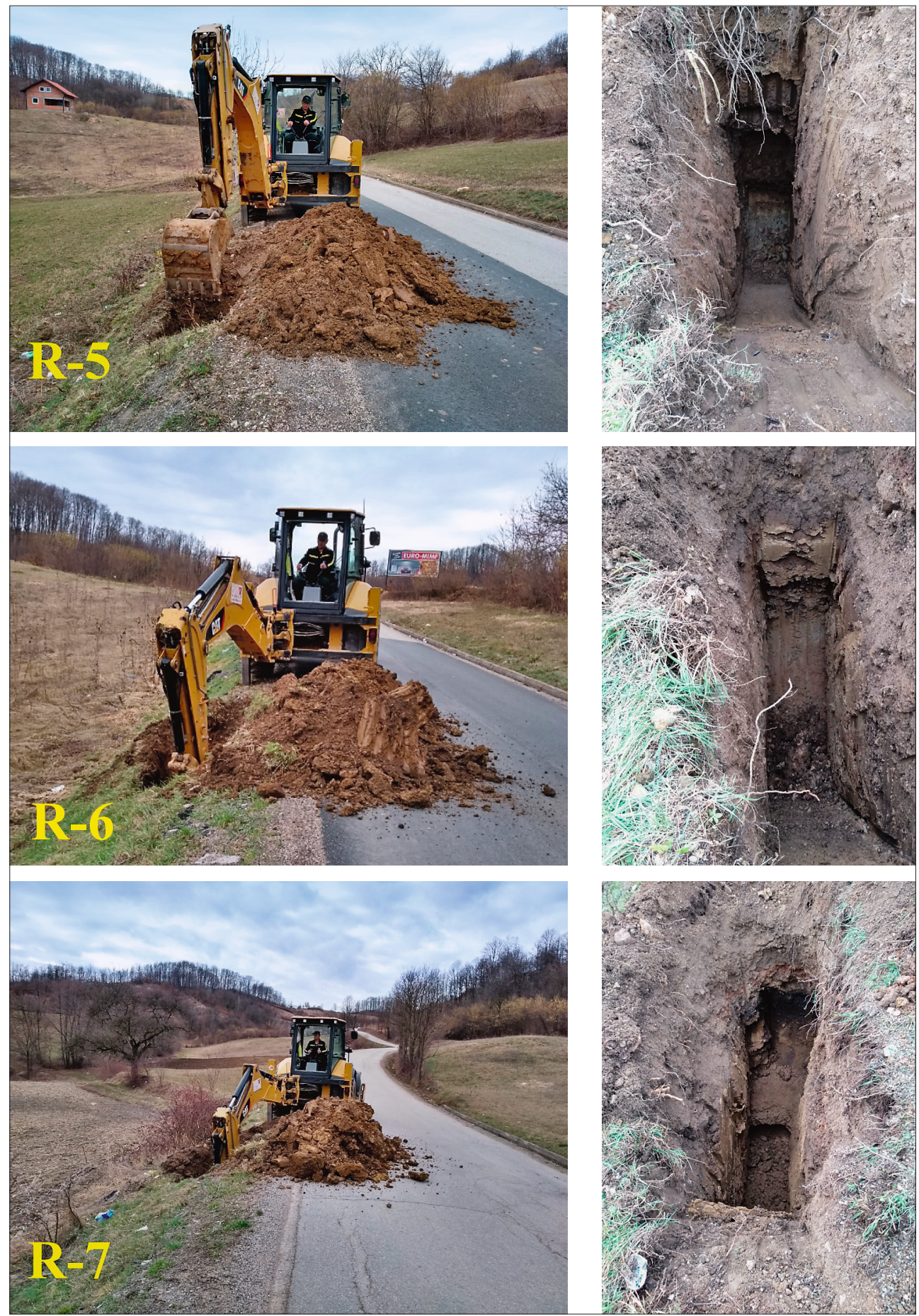

Figure 7: Exploration excavations R-5, R-6 and R-7

rinsing with a jet of water (see Figure 13) on sieves with openings of $0.8,0.5,0.25$, and $0.15 \mathrm{~mm}$, the microfossil material remains, which is then dried and examined under a binocular Leica EZ4D microscope. Foraminifera were determined according to Cicha et al. (1998).

\section{Results}

Microscopic determination of foraminifera was performed using a Leica EZ4D microscope with the appro- priate software package (see Figure 14). Separate samples were carefully analyzed in detail and all fossils were extracted from them. Based on the association of fossils in individual samples, the stratigraphic level was defined. All fossil names were checked by relevant bases (World Register of Marine Species) and revised. Table 2 shows sampling points and samples and Table 3 shows the determination of fossils in individual samples. Some species of foraminifera are shown in the Figure 15. 

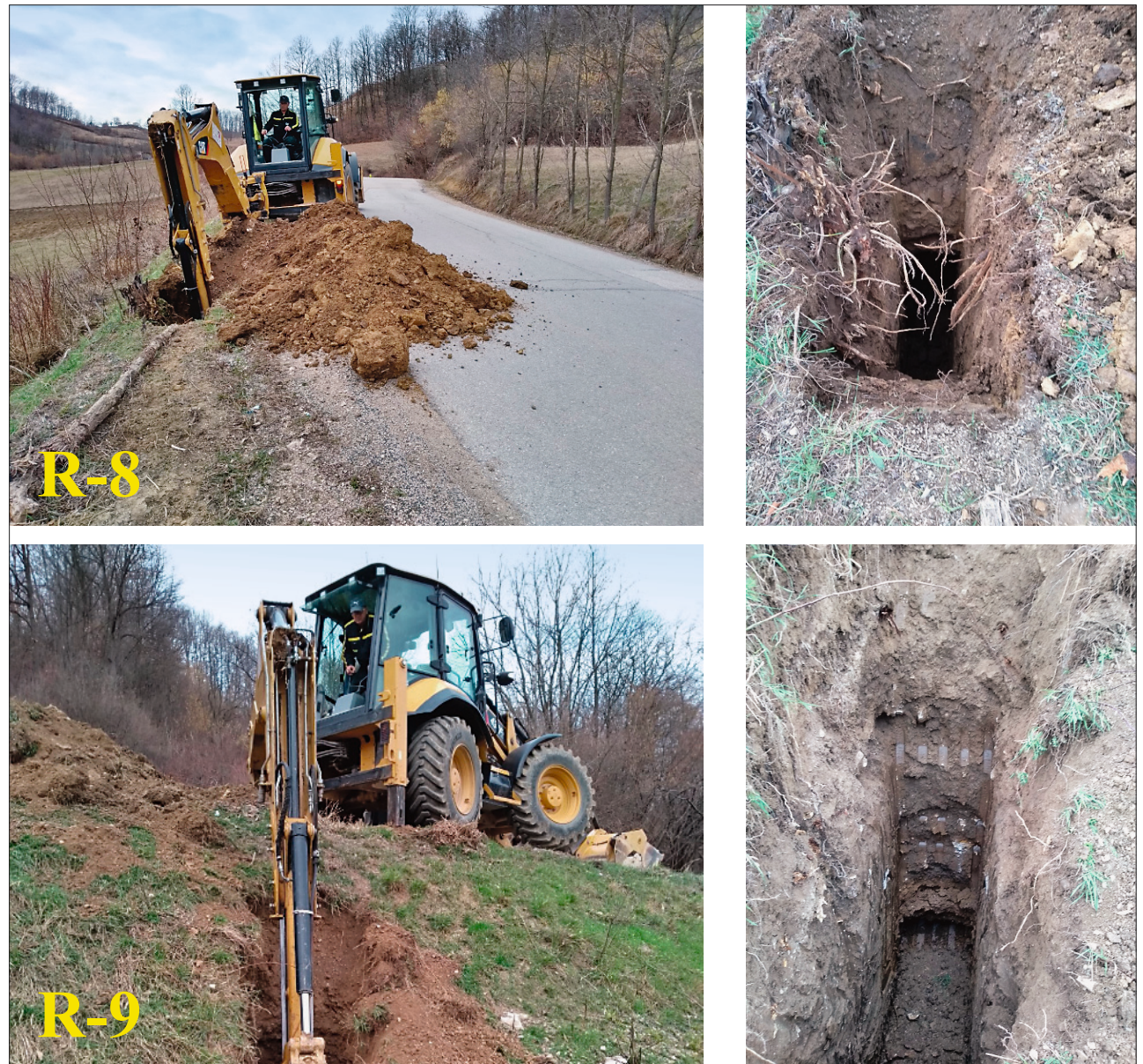

Figure 8: Exploration excavations R-8 and R-9

Table 1: Coordinates of sampling points

\begin{tabular}{|c|c|c|c|c|}
\hline \multirow{2}{*}{$\begin{array}{l}\text { Marking boreholes } \\
\text { and excavations }\end{array}$} & \multicolumn{2}{|c|}{ Gauss-Krieger coordinates } & \multicolumn{2}{|c|}{ Geographic coordinates } \\
\hline & $\mathbf{x}$ & $\mathbf{y}$ & latitude & longitude \\
\hline B-1 & 4950309 & 6536310 & $44^{\circ} 41^{\prime} 46.84^{\prime \prime} \mathrm{N}$ & $18^{\circ} 27^{\prime} 10.99^{\prime \prime} \mathrm{E}$ \\
\hline B-2 & 4950281 & 6536226 & $44^{\circ} 41^{\prime} 45.95^{\prime \prime} \mathrm{N}$ & $18^{\circ} 27^{\prime} 7.17^{\prime \prime} \mathrm{E}$ \\
\hline B-3 & 4950262 & 6536189 & $44^{\circ} 41^{\prime} 45.34^{\prime \prime} \mathrm{N}$ & $18^{\circ} 27^{\prime} 5.49^{\prime \prime} \mathrm{E}$ \\
\hline B-4 & 4950241 & 6536110 & $44^{\circ} 41^{\prime} 44.68^{\prime \prime} \mathrm{N}$ & $18^{\circ} 27^{\prime} 1.89^{\prime \prime} \mathrm{E}$ \\
\hline B-5 & 4950224 & 6536044 & $44^{\circ} 41^{\prime} 44.14^{\prime \prime} \mathrm{N}$ & $18^{\circ} 26^{\prime} 58.89^{\prime \prime} \mathrm{E}$ \\
\hline B-6 & 4950228 & 6535997 & $44^{\circ} 41^{\prime} 44.28^{\prime \prime} \mathrm{N}$ & $18^{\circ} 26^{\prime} 56.76^{\prime \prime} \mathrm{E}$ \\
\hline B-7 & 4950206 & 6535900 & $44^{\circ} 41^{\prime} 43.58^{\prime \prime} \mathrm{N}$ & $18^{\circ} 26^{\prime} 52.35^{\prime \prime} \mathrm{E}$ \\
\hline B-8 & 4950283 & 6535695 & $44^{\circ} 41^{\prime} 46.11^{\prime \prime} \mathrm{N}$ & $18^{\circ} 26^{\prime} 43.05^{\prime \prime} \mathrm{E}$ \\
\hline $\mathrm{R}-1$ & 4950303 & 6536313 & $44^{\circ} 41^{\prime} 46.65^{\prime \prime} \mathrm{N}$ & $18^{\circ} 27^{\prime} 11.13^{\prime \prime} \mathrm{E}$ \\
\hline $\mathrm{R}-2$ & 4950270 & 6536234 & $44^{\circ} 41^{\prime} 45.59^{\prime \prime} \mathrm{N}$ & $18^{\circ} 27^{\prime} 7.53^{\prime \prime} \mathrm{E}$ \\
\hline $\mathrm{R}-3$ & 4950252 & 6536193 & $44^{\circ} 41^{\prime} 45.02^{\prime \prime} \mathrm{N}$ & $18^{\circ} 27^{\prime} 5.67^{\prime \prime} \mathrm{E}$ \\
\hline $\mathrm{R}-4$ & 4950233 & 6536110 & $44^{\circ} 41^{\prime} 44.42^{\prime \prime} \mathrm{N}$ & $18^{\circ} 27^{\prime} 1.89^{\prime \prime} \mathrm{E}$ \\
\hline $\mathrm{R}-5$ & 4950222 & 6536035 & $44^{\circ} 41^{\prime} 44.07^{\prime \prime N}$ & $18^{\circ} 26^{\prime} 58.48^{\prime \prime} \mathrm{E}$ \\
\hline $\mathrm{R}-6$ & 4950213 & 6535973 & $44^{\circ} 41^{\prime} 43.79^{\prime \prime} \mathrm{N}$ & $18^{\circ} 26^{\prime} 55.66^{\prime \prime} \mathrm{E}$ \\
\hline $\mathrm{R}-7$ & 4950198 & 6535897 & $44^{\circ} 41^{\prime} 43.32^{\prime \prime} \mathrm{N}$ & $18^{\circ} 26^{\prime} 52.21^{\prime \prime} \mathrm{E}$ \\
\hline $\mathrm{R}-8$ & 4950223 & 6535830 & $44^{\circ} 41^{\prime} 44.14^{\prime \prime} \mathrm{N}$ & $18^{\circ} 26^{\prime} 49.17^{\prime \prime} \mathrm{E}$ \\
\hline R-9 & 4950262 & 6535784 & $44^{\circ} 41^{\prime} 45.42^{\prime \prime} \mathrm{N}$ & $18^{\circ} 26^{\prime} 47.09^{\prime \prime} \mathrm{E}$ \\
\hline
\end{tabular}


B-1

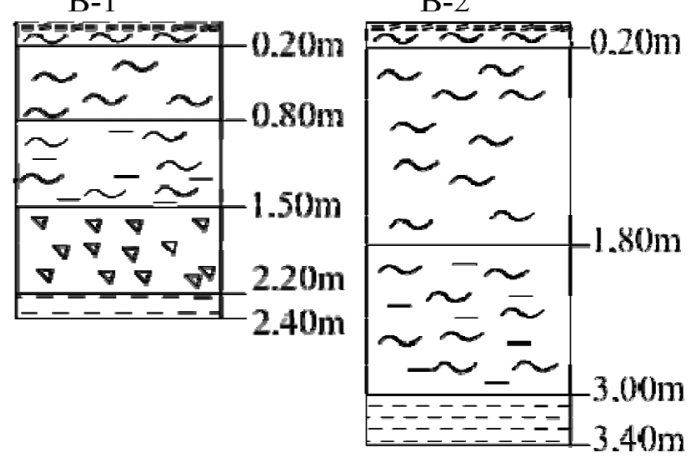

B-5

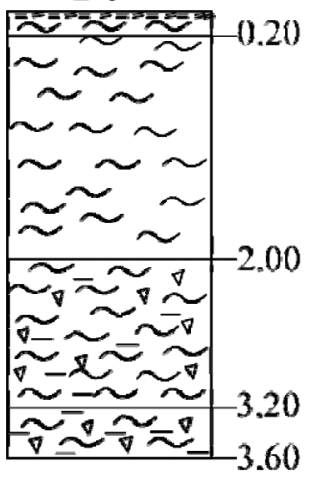

B-3
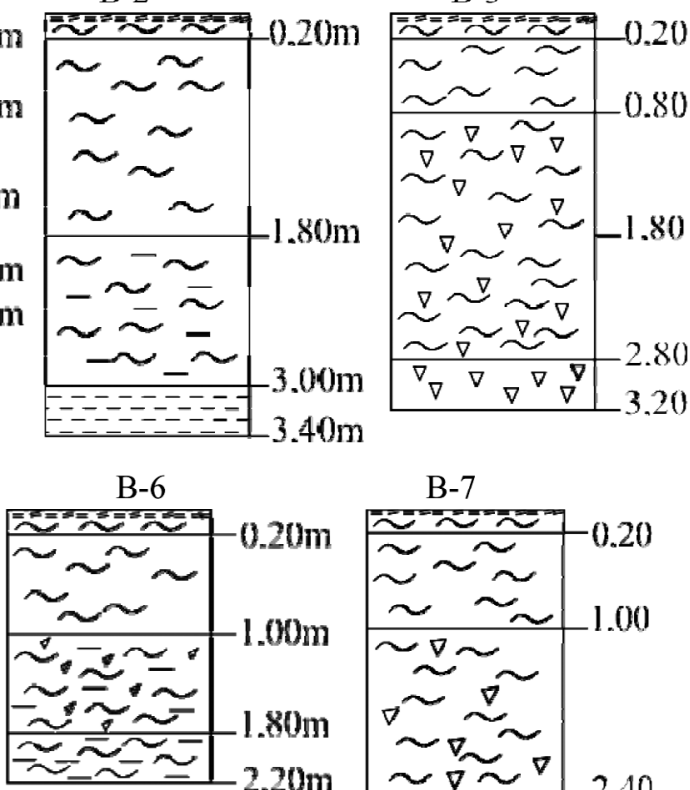

B-7

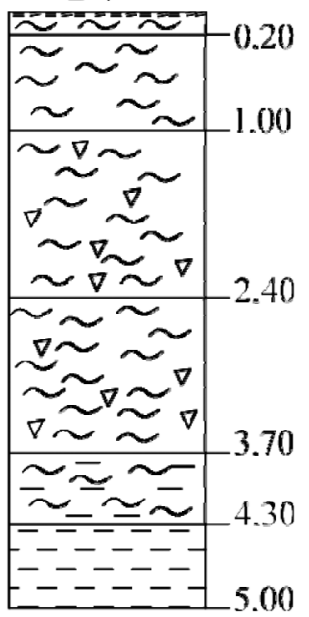

B-4

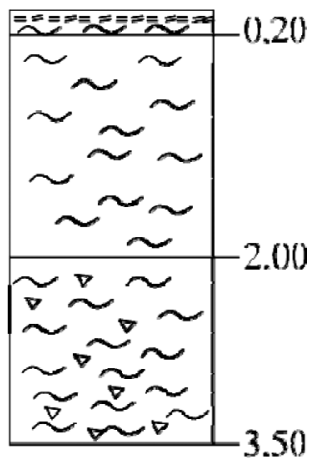

B-8

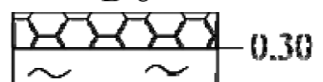

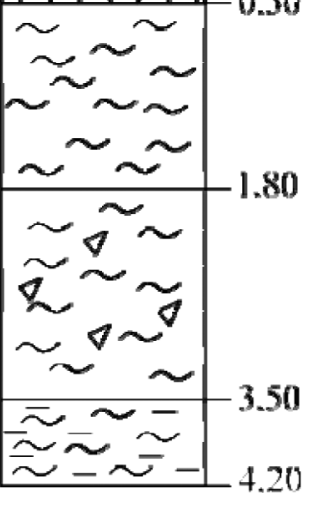

4.20

Figure 9: Exploration boreholes profiles in the research area
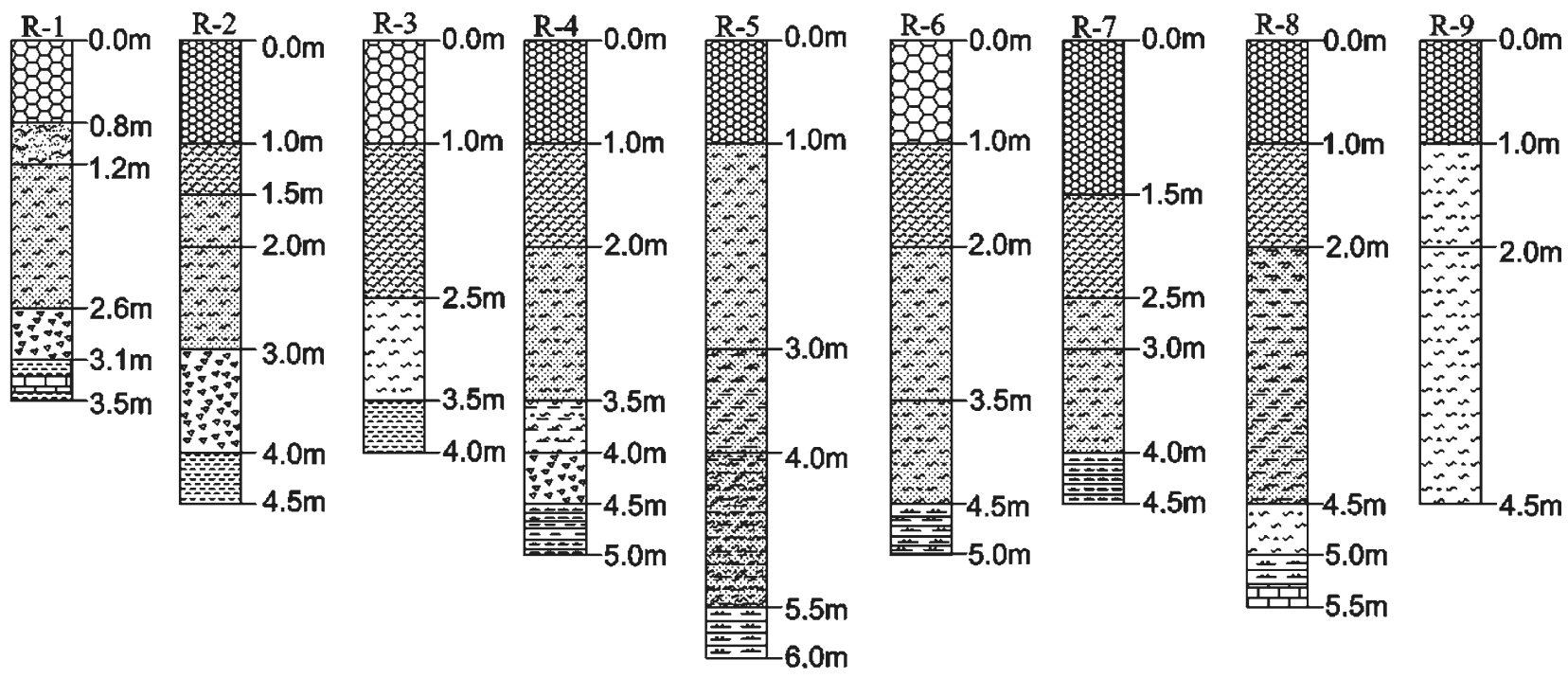

Figure 10: Exploration excavations profiles in the research area

\section{Discussion}

In Bosnia and Herzegovina, marine Miocene deposits are present in northern Bosnia and are covered with younger deposits, an aggravating circumstance for performing paleogeographic reconstructions. In addition, data on the lithofacial and biofacial characteristics of the Miocene sediments are not available in the parts where these sediments are covered leaving many questions unresolved. Geological characteristics have been studied in detail on numerous outcrops of the Miocene sediments, while a very small number of published papers present paleogeographic reconstructions or sedimentological analyses. A detailed analysis of the sedimentation conditions of the Badenian and Sarmatian facies of northern Bosnia was performed by Vrabac, S. (1989). Geological 


\section{LEGEND}

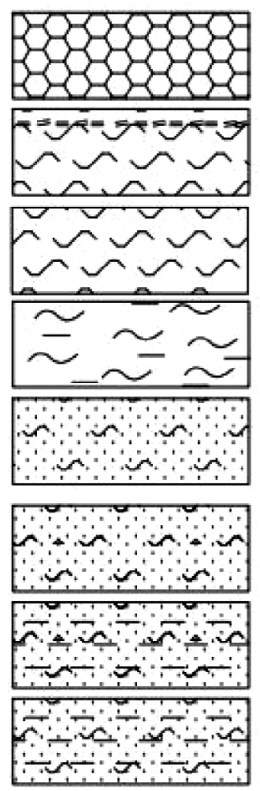

Embankment

Clay humus

Clay

Marly clay

Silty clay

\section{Silty clay with debris \\ Silty marly clay with debris \\ Silty marly clay}

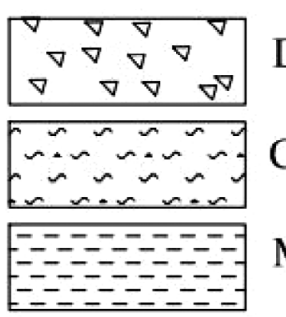

Debris

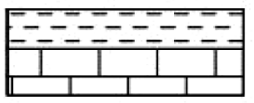

Marls and limestones

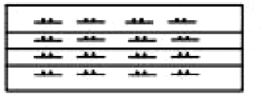

Siltstones

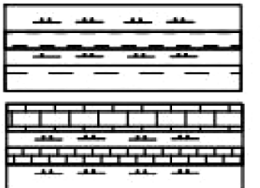

Siltstones and marls

Limestones and siltstones

Figure 11: Legend for exploration boreholes and excavations
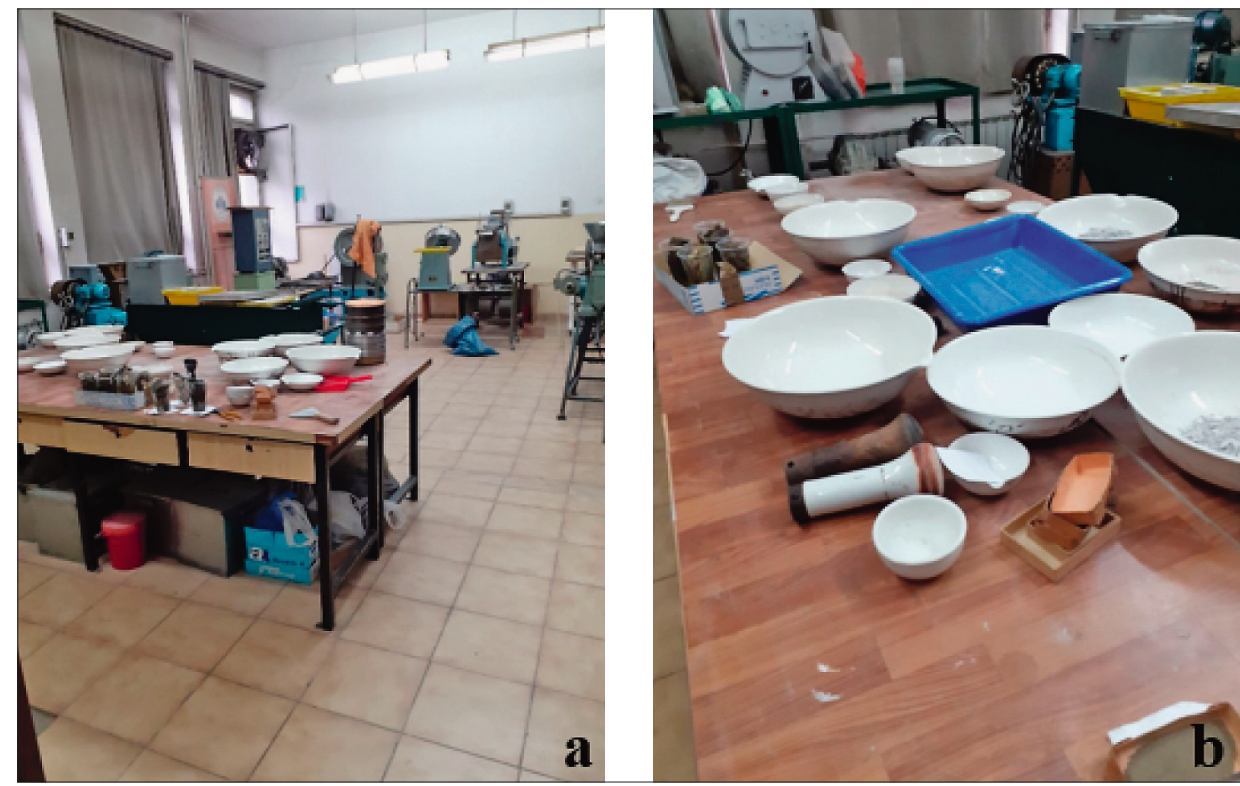

Figure 12: Laboratory at the Faculty of Mining, Geology, and Civil Engineering in Tuzla, with sample probes (a) and sample drying accessories (b).

mapping of the exploration works determined the sediments that are present on this terrain profile. Lithological members are represented by siltstones, marls, and limestones. Based on the presence of microforaminifera in analyzed samples, the stratigraphic level of Lower Badenian was defined. Within this stratigraphic level, only one zone has been identified: Trilobatus trilobus and Orbulina suturalis representing the upper part of the Lower Badenian. This zone was previously isolated in the Lower Badenian sediments of the Ugljevik area (Petrović et al., 1990; Vrabac \& Mihajlović, 1990) and the Tuzla Basin (Petrović et al., 1990; Vrabac \& Corić,
2008; Ferhatbegović, 2013). The site is characterized by a rich microfossil community in which planktonic forms dominate, while benthic forms are present to a lesser extent. Trilobatus trilobus, Orbulina suturalis, and Globigerina bulloides appear as dominant and leading fossils. The Lower Badenian sediments of this area correspond in age to the Lagenid zone of the Vienna Basin. Based on the rich and diverse microfossil community, it can be concluded that the gas regime was favorable and that the water temperature was warm. The warm-loving foraminifera Trilobatus trilobus, Orbulina suturalis, Globigerinella, etc. (Rupp \& Hohenegger, 

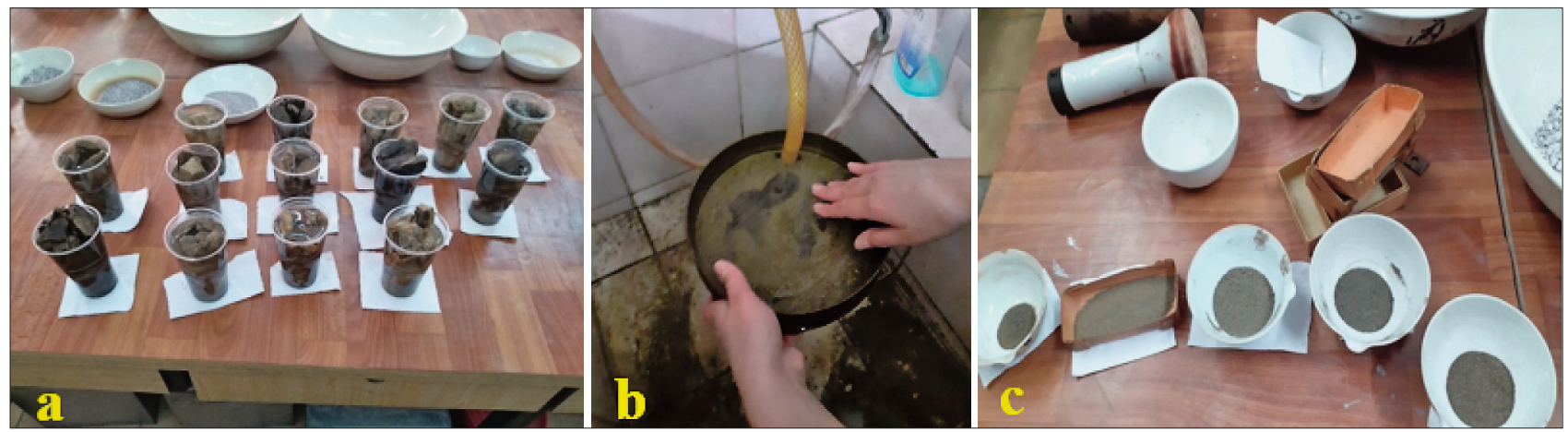

Figure 13: Preparation of samples (a), sample rinsing (b) and dried samples (c).

Table 2: Sampling points and samples

\begin{tabular}{|l|l|}
\hline B-boreholes, R-excavations & Samples \\
\hline R1 & 1 \\
\hline B1 & $1 \mathrm{a}$ \\
\hline R3 & 3 \\
\hline B3 & $3 \mathrm{a}$ \\
\hline R4 & 4 \\
\hline B4 & $4 \mathrm{a}$ \\
\hline R5 & 5 \\
\hline B5 & $5 \mathrm{a}$ \\
\hline R6 & 6 \\
\hline B6 & $6 \mathrm{a}$ \\
\hline R7 & 7 \\
\hline B7 & $7 \mathrm{a}$ \\
\hline
\end{tabular}

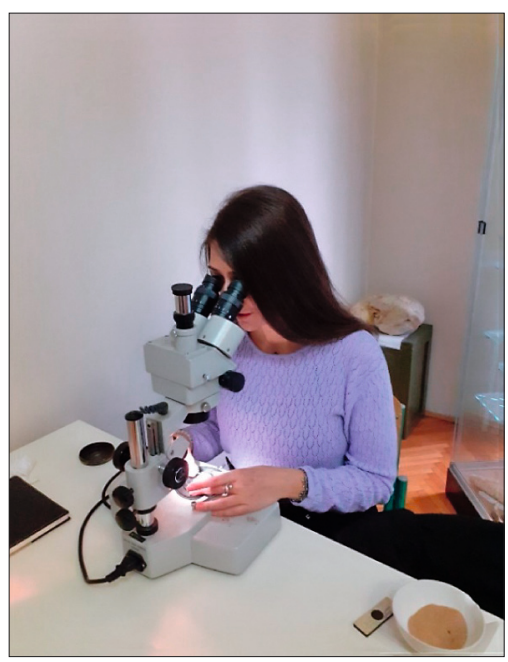

Figure 14: Leica EZ4 4 microscope

Table 3: Representation of microfossils in samples

\section{Lower Badenian-zone Trilobatus trilobus and Orbulina suturalis}

\begin{tabular}{|c|c|c|c|c|c|c|c|c|c|c|c|c|}
\hline \multirow[t]{2}{*}{ Microfossils } & \multicolumn{12}{|c|}{ Samples } \\
\hline & 1 & 1a & 3 & $3 a$ & 4 & $4 a$ & 5 & $5 a$ & 6 & $6 a$ & 7 & $7 \mathrm{a}$ \\
\hline Alfredosilvestris levinsoni Andersen, 1961 & & & & & + & + & & & & & & \\
\hline Asterigerinata planorbis (d’Orbigny, 1846) & & & & & + & + & & & & & + & + \\
\hline Bulimina elongata d Orbigny, 1846 & & & + & + & + & + & & & & & + & + \\
\hline Cibicidoides ungerianus (d’Orbigny, 1846) & & & & & & & + & + & & & + & + \\
\hline Dentoglobigerina altispira (Cushman \& Jarvis, 1936) & + & + & + & & & & & & + & + & & \\
\hline Elphidium crispum (Linnaeus, 1758) & & & & & & & & & & & + & + \\
\hline Elphidium flexuosum (d`Orbigny, 1846) & & & + & + & & & & & & & & \\
\hline Globigerina bulloides d’Orbigny, 1826 & + & + & + & + & + & & & & + & + & + & + \\
\hline Globigerina diplostoma Reuss, 1850 & & & & & + & + & & & & & & \\
\hline Globigerinella regularis d Orbigny, 1846 & & & + & + & + & + & + & + & & & & \\
\hline Lobatula lobatula (Walker \& Jacob, 1798) & & & & & & & & & + & + & & \\
\hline Nonion commune (d Orbigny, 1846) & & + & & & & & & & + & + & & \\
\hline Orbulina suturalis Brönimann, 1951 & & & + & + & & & & & & & & \\
\hline Pyramidulina raphanistrum (Linnaeus, 1758) & & & + & + & + & + & & & & & & \\
\hline Trilobatus trilobus (Reuss, 1850) & + & + & + & + & + & + & + & + & + & + & + & + \\
\hline
\end{tabular}




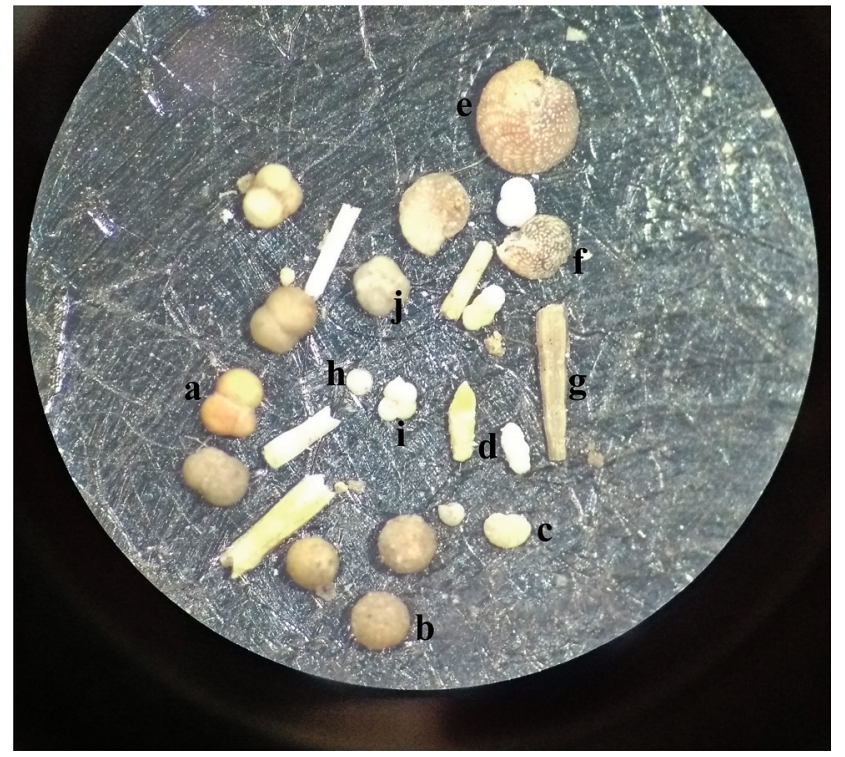

Figure 15: Some species of foraminifera from samples: a) Trilobatus trilobus (Reuss,1850); b) Orbulina suturalis Brönimann, 1951; c) Nonion commune (d Orbigny, 1846);

d) Bulimina elongata d Orbigny, 1846; e) Elphidium crispum (Linnaeus, 1758); f) Elphidium flexuosum (d Orbigny, 1846);g) Pyramidulina raphanistrum (Linnaeus, 1758);

h) Asterigerinata planorbis (d Orbigny, 1846);

i) Globigerinella regularis d'Orbigny, 1846;

j) Dentoglobigerina altispira (Cushman \& Jarvis, 1936)

2008) and reef limestones indicate that the seawater was warm during the lower Badenian in the investigated area. The presence of a large number of echinoid remains, known as stenohaline organisms, indicates that the sea in this area in the Lower Badenian had normal salinity. Numerous planktonic foraminifera indicates the wide connection of this sedimentary basin with the open sea. Based on the number of planktonic forms with carbonate shells and the richness of oxygen, it can be concluded that the character of the environment was basic, not acidic.

\section{Conclusions}

Based on the performed geological, micropaleontological, and biostratigraphic analyses, it is proven that the Lower Badenian sediments are present along the whole research area. The Lower Badenian sediments are lithologically represented by grey and layered marls, limestones, and platy siltstones of a yellowish-brown to grey colour. Based on index microfossils, one local foraminiferal zone has been determined: zone with Trilobatus trilobus and Orbulina suturalis, representing the upper part of the Lower Badenian. Trilobatus trilobus (REUSS), Orbulina suturalis Brönimann and Globigerina bulloides d Orbigny appear as dominant and leading fossils. Some other planktonic taxa e.g. Globigerinella regularis (d'Orbigny), Globigerina diplostoma Reuss, Dentoglobigerina altispira (Cushman \& Jarvis), also occur in the samples. Benthic forms are scarce and are mainly represented by the genera Bulimina, Nonion, and Cibicidoides. Analysis and synthesis of data obtained from this study will be the foundation for preparing detailed geological maps, paleogeographic reconstructions, structural-tectonic analyses, and other specialistic studies.

\section{References}

Atanacković, M. (1977): Marinski tip miocena (Marine type of Miocene).Geol.BiH, III, 119-143. (in Serbian)

Atanacković, M. (1981): Analiza paleogeografskih i paleoekoloških prilika u tortonskom moru severne Bosne (Analysis of paleogeographic and paleoecological conditions in the Torton Sea of northern Bosnia). Radio Sarajevo, III program, 32, Sarajevo.

Cicha, I., Rupp, C. \&, Ctyroka, J. (1998): Oligocene-Miocene foraminifera of the Central Paratethys. Abhandlungen der Senckenbergischen Naturforschenden Gesellschaft, Band 549, Frankfurt, 1-325p.

Čičić, S. (1964): Geološki sastav i tektonika sjeveroistočnog dijela planine Majevice s naročitim osvrtom na geološko ekonomski značaj ležišta mrkog uglja (Geological composition and tectonics of the northeastern part of the Majevica mountain with special reference to the geological and economic significance of brown coal deposits). Geološki glasnik 6, Sarajevo, 1-175. (in Bosnian)

Čičić, S. \& Jovanović, Č. (1987): Prilog poznavanju geološke građe, geneze, evolucije i tektonike Tuzlanskog bazena sa širim osvrtom na prilike u slivu rijeke Jale i Soline (Contribution to the knowledge of the geological structure, genesis, evolution and tectonics of the Tuzla Basin with a broader overview of the conditions in the Jala and Solina river basins). Geol.glasnik, 30,113-157. (in Bosnian)

Čičić, S. (2002): Geološki sastav i tektonika Bosne i Hercegovine (Geological composition and tectonics of Bosnia and Herzegovina). Earth Science Institute, 1-350p. (in Bosnian)

Ćorić, S., Vrabac, S., Ferhatbegović, Z. \&, Đulović, I. (2007): Biostratigraphy of Middle Miocene sediments from the Tuzla basin (north-eastern Bosnia) based on foraminifera and Calcareous nannoplankton. Neogene of Central and South-Eastern Europe, 2, International Workshop, Joannea - Geologie Paläontologie, 9, Graz, 21-23.

Đulović, I, Vrabac. S. \&, Ferhatbegović, Z. (2010): Tektonske karakteristike sjeverozapadnog oboda Majevice (Tectonic characteristics of the northwestern rim of Majevica). Zbornik radova RGGF-a, Tuzla, 157-164. (in Bosnian)

Eremia, M. (1970): Neke paleogeografske karakteristike tortonskih sedimenta severne Bosne (Some paleogeographic characteristics of tortonian sediments of northern Bosnia). VII kongres geol.SFRJ, Zagreb. (in Serbian)

Ferhatbegović, Z. (2001): Biostratigrafske i inženjerskogeološke karakteristike krovinskih sedimenata ležišta kamena soli u Tuzli (Biostratigraphic and engineering geological characteristics of roof sediments of salt rock deposits in Tuzla). Magistarski rad. Univerzitet u Tuzli. (in Bosnian)

Ferhatbegović, Z. (2003): Biostratigrafske karakteristike krovinskih sedimenata ležišta kamene soli u Tuzli (Biostrati- 
graphic characteristics of roof sediments of rock salt deposits in Tuzla).Geološki glasnik 35, Sarajevo, 169-179. (in Bosnian)

Ferhatbegović, Z. (2004): Geološke karakteristike središnjeg dijela Tuzlanskog bazena (Geological characteristics of the central part of the Tuzla basin). Doktorska disertacija, Univerzitet u Tuzli. (in Bosnian)

Ferhatbegović, Z. (2006): Geološke karakteristike donjomiocenskih sedimenata u središnjem dijelu Tuzlanskog bazena (Geological characteristics of Lower Miocene sediments in the central part of the Tuzla Basin). Geološki glasnik, 36, Sarajevo, 161-181. (in Bosnian)

Ferhatbegović Z. \&, Vrabac S. (2006): Paleontološke i biostratigrafske karakteristike badenskih sedimenata u središnjem dijelu

Tuzlanskog bazena (Paleontological and biostratigraphic characteristics of Badenian sediments in the central part of the Tuzla basin) Geološki glasnik, 36, Sarajevo, 183190. (in Bosnian)

Ferhatbegović, Z. (2010): Geološke karakteristike središnjeg dijela Tuzlanskog bazena (Geological characteristics of the central part of the Tuzla basin). Monografija, Univerzitet u Tuzli, Tuzla, 1-82. (in Bosnian)

Ferhatbegović, Z., Vrabac, S., Jahić, A. \&, Đulović, I. (2013): Quantitative and qualitative analysis of foraminifera in the Middle Miocene of salt deposit Tetima (north-east Bosnia). Geol. vyzk.Slez., Brno,13-17.

Ferhatbegović, Z. \&, Jahić, A. (2013): Rekonstrukcija uslova sedimentacije krovinskih sedimenta u profilu istražno eksploatacione bušotine B-71 na ležištu kamene soli Tetima (Reconstruction of sedimentation conditions of roof sediments in the profile of exploration-exploitation borehole $B-71$ on the stone salt deposit Tetima).Zbornik radova $\mathrm{V}$ savjetovanje geologa Bosne i Hercegovine sa međunarodnim učešćem, Pale, 34-38. (in Bosnian)

Ferhatbegović, Z. \&, Jahić, A. (2013): Foraminiferske zone donjeg badena u središnjem dijelu Tuzlanskog bazena (Foraminiferal zones of the Lower Baden in the central part of the Tuzla Basin). Zbornik radova V savjetovanje geologa Bosne i Hercegovine sa međunarodnim učešćem, Pale, 111-115. (in Bosnian)

Ferhatbegović, Z., (2018): Osnove paleontologije (Fundamentals of paleontology). Univerzitet u Tuzli, Tuzla, 216 p.(in Bosnian)

Katzer, F. (1903): Geologischer Führer durch Bosnien und die Hercegovina. Hrsg. anlässlich des IX. Internationalen

Geologencongresses von der Landesregierung in Sarajevo, Landesdruckerei, Sarajevo, 1-280p.

Kranjec, V. (1969): Geološka građa šireg tuzlanskog područja (Geological structure of the wider Tuzla area). Doktorska disertacija, FSD. RGGF, Tuzla. (in Croatian)

Laušević, M. \& Jovanović, Č. (1983): Osnovna geološka karta SFRJ 1: 100000. Tumač za list Doboj (Basic Geological Map of SFRY 1:100000, Geology of the Doboj sheet- in Serbian). Savezni geološki Zavod Beograd, 49p.

Pantić, N., Mihajlović, Đ. \&, Vrabac, S. (1988): Fosilna flora badenijana okoline Tuzle (Fossil flora of the Badenian area around Tuzla). Geol.anali Balk. pol., 51, Beograd, 321-327. (in Serbian)
Petrović, M. (1979/80): Biostratigrafski značaj srednjemiocenskih foraminifera iz bušotina Tuzlanskog bazena (Biostratigraphic significance of Middle Miocene foraminifera from boreholes in the Tuzla Basin). Geološki anali Balk.pol.,43/44, Beograd,155-203. (in Serbian)

Petrović, M., Eremija, M. \&, Rundić, LJ.(1990): Uporedni biostratigrafski pregled badenskog kata okoline Tuzle i Ugljevika (Comparative biostratigraphic review of the Baden floor around Tuzla and Ugljevik). Ohrid, 161. (in Serbian)

Rupp, C., Hohenegger, J. (2008): Paleoecology of planktonic foraminifera from the Baden-Sooss section ( Middle Miocene, Badenian,

Viena Basin Austria). Geologica Carpathica, Bratislava, 59, 425-445.

Soklić, I. (1964): Postanak i struktura tuzlanskog Bazena (Origin and structure of the Tuzla Basin). Geološki glasnik 10, Sarajevo, 5-25.(in Croation)

Soklić, I. (1982): Stratigrafija i starost sononosnih naslaga grada Tuzle (Stratigraphy and age of salt deposits of the city of Tuzla). ANU BiH, knj., LXXI, 135-151. (in Croatian)

Soklić, I.(1988): Velika sarmatska transgresija u panonskom bazenu (Great Sarmatian transgression in the Pannonian basin). Naučni skup: Minerali stijene, izumrli i živi svijet BiH, Zemaljski muzej BiH, Sarajevo,145-155. (in Croation)

Soklić, I. \& Vrabac, S. (1995): Fauna molusca i biostratigrafija sarmata sjeverne Bosne (Mollusk fauna and biostratigraphy of Sarmatian northern Bosnia). Geol.glasnik, 33, 3143. (in Croatian)

Soklić, I. (2001): Fosilna flora i fauna Bosne i Hercegovine (Fossil flora and fauna of Bosnia and Herzegovina). Akademija nauke i umjetnosti Bosne i Hercegovine, Sarajevo, 585. (in Croatian)

Stevanović, P. \& Eremija, M. (1960): Miocen Donje Tuzle (Miocene of Donja Tuzla). Geološki anali Balk.pol., 27, 45-102. (in Serbian)

Stojčić, B., Marinković, R. \&, Sofilj, J. (1978): Identifikacija Karpatiena (gornji helvet) u području između Vrbasa i Ukrine (Identification of Karpatian (upper helvet) in the area between Vrbas and Ukrina). Zbornik radova IX kongresa Jugosl., Sarajevo, 250-256. (in Croatian)

Vrabac, S. (1986): Paleogeografija sjeverne Bosne u badenskom vijeku (Paleogeography of northern Bosnia in the Badenian century). Univerzitet u Tuzli, magistarski rad, Tuzla, 116p. (in Bosnian).

Vrabac, S.,(1987): Paleogeografija sjeverne Bosne u badenskom vijeku (Paleogeography of northern Bosnia in the Badenian). Geol.glasnik, 31/32, Sarajevo, 36-68. (in Bosnian)

Vrabac, S. (1989): Paleogeografija južnog oboda Panonskog basena u badenu i sarmatu (Paleogeography of the southern rim of the Pannonian Basin in Badenian and Sarmatian). Univerzitet u Tuzli, doktorska disertacija, Tuzla, 208p. (in Bosnian)

Vrabac, S., Mihajlović, Đ. (1990): Paleontološko-biostratigrafske odlike i odnos badena i sarmata na površinskom kopu Bogutovo Selo kod Ugljevika (SI Bosna) (Paleontological-biostratigraphic features and the relationship between Baden and Sarmatian at 
Bogutovo Selo surface mine near Ugljevik (NE Bosnia). XII kongres geologa SFRJ, Ohrid, knj.1, 312-358p. (in Bosnian)

Vrabac, S. \& Mihajlović, Đ. (1990): Paleontološke i biostratigrafske odlike krovinskih sedimenta ležišta kamene soli Tušanj u Tuzli (Paleontological and biostratigraphic features of roof sediments of Tušanj rock salt deposit in Tuzla). Geološki anali Balk.pol, 55, 297-304. (in Bosnian)

Vrabac, S. (1991): O nalasku marinskih fosila u sonoj formaciji Tuzlanskog bazena sa osvrtom na starost i genezu ležišta kamene soli (On the finding of marine fossils in the salt formation of the Tuzla basin with reference to the age and genesis of rock salt deposits). Geol.anali Balk.pol.,55, 189-196. (in Bosnian)

Vrabac, S. \&, Ferhatbegović, Z. (1997): Geološka građa sedimenata na brdu Kicelj u Tuzli (Geological structure of sediments on the hill Kicelj in Tuzla). Zbornik radova RGF,21, Tuzla, 35-39. (in Bosnian)

Vrabac, S. (1999): Facijalne i biostratigrafske odlike badena i sarmata sjeverne Bosne (Facial and biostratigraphic features of the Badenian and Sarmatian of northern Bosnia). Rud.Geol.Građ. fakultet, Tuzla.(in Bosnian)

Vrabac, S., Ferhatbegović, Z. \&, Đulović, I. (2000): O nalasku diskordancije između badenskih i sarmatskih krečnjaka na sjevernom obodu Majevice (On the finding of discordance between Badenian and Sarmatian limestones on the northern edge of Majevica). Zabornik radova RGGF-a, XXII/1, Tuzla, 169-172. (in Bosnian)

Vrabac, S., Ferhatbegović, Z. \&., Đulović, I. (2005): Paleogeografija sjeverne Bosne u sarmatu (Paleogeography of northern Bosnia in Sarmatian). Zbornik radova RGGF Univerzitet u Tuzli, XXIX/II, 189-192, Tuzla.

Vrabac, S. (2005): Istorijska geologija (Historical geology). Univerzitet u Tuzli, Tuzla, 213p. (in Bosnian)
Vrabac, S. (2007): Paleogeografija (Paleogeography). Univerzitet u Tuzli, Tuzla, 139p. (in Bosnian)

Vrabac, S., Ferhatbegović, Z. \&, Đulović, I. (2007): Paleogeografija sjeverne Bosne u miocenu (Paleogeography of northern Bosnia in the Miocene). Zbornik radova RGGF-a Univerziteta u Tuzli, Tuzla, 55-59. (in Bosnian)

Vrabac, S., Ferhatbegović, Z. \&, Đulović, I. (2007): Litološkopaleontološke i biostratigrafske odlike marinskih miocenskih Tuzlanskog bazena (Lithological-paleontological and biostratigraphic features of marine Miocene Tuzla basin). Zbornik radova RGGF-a Univerziteta u Tuzli, Tuzla, 5-12. (in Bosnian)

Vrabac, S., Ferhatbegović, Z. \&, Đulović, I. (2007): Paleogeografija sjeverne Bosne u miocenu (Paleogeography of northern Bosnia in the Miocene). Zbornik radova RGGF-a Univerziteta u Tuzli, Tuzla, 55-59. (in Bosnian)

Vrabac, S. \& Ćorić, S. (2008) : Revizija “karpata” Tuzlanskog bazena sa osvrtom na stratigrafski položaj sone formacije (Revision of the "Karpatian" of the Tuzla Basin with a review of the stratigraphic position of the salt formation). Geološki glasnik, Sarajevo, 37,71-81. (in Bosnian)

Vrabac, S., Ferhatbegović, Z., Đulović, I. \&. Bijedić., Dž. (2008): Nalazak morskih fosila u sonoj formaciji ležišta kamene soli Tetima kod Tuzle (Finding of sea fossils in the sonic formation of the Tetima rock salt deposit near Tuzla). III savjetovanje geologa $\mathrm{BiH}$ sa međunarodnim učešćem, Zbornik radova, Neum 53-60. (in Bosnian)

Vrabac, S., Ferhatbegović, Z., Đulović, I. \& Jahić, A. (2013): Biostratigraphic characteristics of the Badenian and Sarmatian of the rock salt deposit Tetima near Tuzla. Neogene and Quaternary stratigraphy actual terminology and nomenclature, Belgrade,15-17.(in Bosnian)

\section{SAŽETAK}

\section{Paleontološke i biostratigrafske karakteristike badenskih naslaga na profilu Srebrenik - Donja Orahovica (Bosna i Hercegovina)}

U radu su opisana biostratigrafska i paleontološka istraživanja provedena na geološkome profilu Srebrenik - Donja Orahovica. Za istraženo područje, koje je geološki detaljno kartirano, napravljeno je osam istražnih bušotina i devet istražnih raskopa. Uzorci za mikropaleontološka istraživanja uzeti su iz spomenutih istraživačkih radova. Geološko kartiranje terena, kartiranje jezgre istražnih bušotina i raskopa te podatci dobiveni laboratorijskim istraživanjima uzoraka (paleontološka istraživanja) poslužili su kao osnova za izradu geoloških profila i geoloških karata. Mikroskopsko određivanje foraminifera izvedeno je s pomoću Leica EZ4D mikroskopa s odgovarajućim programskim paketom. Na temelju prisutnosti mikroforaminifera definiran je stratigrafski nivo donji baden. Prema mikropaleontološkim i biostratigrafskim analizama unutar ovoga stratigrafskog nivoa određena je jedna lokalna foraminiferska Trilobatus trilobus i Orbulina suturalis zona koja predstavlja gornji dio donjega badena.

\section{Ključne riječi:}

foraminifere, biostratigrafija, donji baden, Bosna i Hercegovina

\section{Author's contribution}

Zijad Ferhatbegović (Associate professor) was responsible for the research idea and planning, fieldwork, supervising micropaleontological analyses, interpretations, and presentation of the results. Amila Avdić (MA geology) conducted fieldwork, collected samples in the field, prepared and determined microfossils. Sumeja Durmić (MA geology) performed geological mapping, collected samples in the field, prepared and determined microfossils. 